\title{
Family-based association study of the BDNF, COMT and serotonin transporter genes and DSM-IV bipolar-I disorder in children Eric Mick*1, Janet Wozniak ${ }^{1}$, Timothy E Wilens ${ }^{1}$, Joseph Biederman ${ }^{1}$ and Stephen V Faraone ${ }^{2,3}$
}

Address: ${ }^{1}$ Department of Psychiatry, Massachusetts General Hospital and Harvard Medical School, Boston, MA, USA, ${ }^{2}$ Department of Psychiatry, SUNY Upstate Medical University, Syracuse, NY, USA and ${ }^{3}$ Department of Neuroscience and Physiology, SUNY Upstate Medical University, Syracuse, NY, USA

Email: Eric Mick* - mick@helix.mgh.harvard.edu; Janet Wozniak - wozniak@helix.mgh.harvard.edu; Timothy E Wilens - twilens@partners.org; Joseph Biederman - biederman@helix.mgh.harvard.edu; Stephen V Faraone - faraones@upstate.edu

* Corresponding author

Published: 4 February 2009

BMC Psychiatry 2009, 9:2 doi:10.1 186/147I-244X-9-2

This article is available from: http://www.biomedcentral.com/I47I-244X/9/2

(c) 2009 Mick et al; licensee BioMed Central Ltd.

This is an Open Access article distributed under the terms of the Creative Commons Attribution License (http://creativecommons.org/licenses/by/2.0), which permits unrestricted use, distribution, and reproduction in any medium, provided the original work is properly cited.
Received: 22 September 2008

Accepted: 4 February 2009

\begin{abstract}
Background: Over the past decade pediatric bipolar disorder has gained recognition as a potentially more severe and heritable form of the disorder. In this report we test for association with genes coding brain-derived neurotrophic factor (BDNF), the serotonin transporter (SLC6A4), and catechol-O-methyltransferase (COMT).

Methods: Bipolar-I affected offspring triads $(\mathrm{N}=173)$ were drawn from 522 individuals with 2 parents in 332 nuclear families recruited for genetic studies of pediatric psychopathology at the Clinical and Research Program in Pediatric Psychopharmacology and Adult ADHD at Massachusetts General Hospital.

Results: We failed to identify an association with the val66 allele in BDNF (OR = I.23, $p=0.36$ ), the COMT-I allele $(O R=1.27, p=0.1)$, or the HTTLPR short allele $(O R=0.87, p=0.38)$.

Conclusion: Our study suggests that the markers examined thus far in COMT and SLC6A4 are not associated with pediatric bipolar disorder and that if the val66met marker in BDNF is associated with pediatric bipolar disorder the magnitude of the association is much smaller than first reported.
\end{abstract}

\section{Background}

Several lines of evidence suggest that the age at onset of bipolar disorder may be a potentially important marker of a more severe and more familial form of the disorder. Consistent with the clinical observations made by Carlson et al [1] 25 years ago, the current literature suggests that pediatric bipolar disorder is associated with severe impairment, rapid cycling, early age at onset and significant psychiatric comorbidity. The presentation of bipolar disorder in children is not unlike that described in adults as mixed mania by McElroy et al [2]: a rapid-cycling and recurrent disorder with poor inter-episode functioning, frequent onset in childhood and adolescence, a high risk of suicide, high risk of substance use disorders, poor response to treatment, a history of poor school performance, and neuropsychological deficits highly suggestive of attention-deficit/hyperactivity disorder [3-11].

Studies of adult subjects with bipolar disorder strongly suggest a genetic component in etiology of the disorder. 
Twin studies [12-17] suggest heritability estimates from $79 \%$ to $93 \%$ for mania/bipolar disorder. Smoller and Finn [18] estimated a 10-fold increase in the recurrence risk $(8.7 \%)$ for bipolar disorder among first-degree relatives of bipolar probands. Likewise, an excess recurrence risk of bipolar disorder has been reported in family studies of affected child probands utilizing DSM-III [19-22], DSM-IIIR [23], and DSM-IV [6,8,10,24] criteria for bipolar disorder. The recurrence risks reported in the pediatric literature $(12-35 \%)$ are considerably higher than estimates of the risk for bipolar disorder in the relatives of adult probands (5-10\%) [18,25].

Despite the evidence documenting that early-onset of bipolar disorder increases the familial recurrence rate, there has been very little molecular genetic research focused on pediatric bipolar disorder. Each of the candidate genes examined for association with pediatric bipolar disorder were selected largely because they are involved with neurotransmitter systems hypothesized to be altered in mood disorders based upon pharmacological response or animal models. However, only five genes have been examined and four of the available reports come from a single sample of approximately 50 families at Washington University [26-29].

The serotonin transporter is a monoamine transporter protein that transports serotonin from synaptic spaces into presynaptic neurons. A 44-bp variable-number tandem-repeat (VNTR) polymorphism in the in the promoter region (HTTLPR) of the serotonin transporter gene (SLC6A4) influences the transcription and function of the transporter [30]. Geller et al [26] found no evidence of association with the serotonin transporter gene (SLC6A4) at the HTTLPR locus (i.e. a 44-bp VNTR in the promoter) in 46 affected offspring trios.

Catechol-O-methyltransferase (COMT) catalyzes the transfer of a methyl group from S-adenosylmethionine to catecholamines, including the neurotransmitters dopamine, epinephrine, and norepinephrine [31]. A variant caused by a G-to-A transition at codon 158 of the COMT gene, results in a valine-to-methionine substitution [32]. Homozygosity for 158 met leads to a 3- to 4 -fold reduction in enzymatic activity, compared with homozygosity for 158val [32] but this marker was also not associated with bipolar disorder in 52 affected offspring trios [27].

Brain-derived neurotrophic factor (BDNF) supports survival of central nervous system neurons and stimulates growth and differentiation of developing neurons [33]. A polymorphism producing an amino acid substitution (valine to methionine) at codon 66 of the BDNF gene may impact intracellular trafficking and activity-dependent secretion of BDNF [34]. Geller et al [28] observed a significant over-transmission of the Val66 allele in 53 affected offspring trios of children with pediatric bipolar disorder.

The glutamate decarboxylase 1 gene (GAD1) is expressed in the brain and codes GAD67 which catalyzes the decarboxylation of glutamate to GABA [35,36]. Geller et al [29] examined the association with a SNP (rs2241165) that tags an over-transmitted haplotype of GAD1 associated with childhood schizophrenia [37] and found that the A allele was also significantly associated with pediatric bipolar disorder.

The dopamine transporter (DAT) plays a central role in regulation of dopaminergic neurotransmission via reuptake of synaptic dopamine [38,39]. We previously conducted a family-based association study of dopamine transporter gene (SLC6A3) in 170 affected offspring trios defined by a child (12.9 \pm 5.3 years of age) with DSM-IV Bipolar-I disorder and found a positive association with one HapMap SNP (rs40184) that survived correction for multiple statistical comparisons $(\mathrm{p}=0.038)$ [40].

In the current report we test for association with the BDNF (Val66Met), COMT (Val158Met), and SLC6A4 (HTTLPR) genes in these families in an attempt to replicate the findings previously reported by Geller et al [26-28]. We were not aware of the association with GAD1 [29] when candidates were being genotyped so cannot report results for that gene. We expected to find over-transmission of the $B D N F$ val66 allele but no evidence of association with makers in either COMT or SLC6A4.

\section{Methods}

Bipolar-I affected offspring triads $(\mathrm{N}=173)$ were drawn from 522 individuals with 2 parents in 332 nuclear families recruited for genetic studies of pediatric psychopathology at the Clinical and Research Program in Pediatric Psychopharmacology and Adult ADHD at Massachusetts General Hospital [41-44]. All studies were sampled from the same source population and used the same assessment methodology regardless of the disorder used to classify subjects as cases. All study procedures were reviewed and approved by the Partners Healthcare Human Research Committee. All subjects' parents or guardians signed written informed consent forms and children older than 7 years of age signed written assent forms.

All affected offspring in the current analysis were diagnosed with bipolar I disorder according to DSM-IV criteria. The DSM-IV requires subjects to meet criterion A for a distinct period of extreme and persistently elevated, expansive or irritable mood lasting at least one week, plus criterion B, manifested by three (four if the mood is irritable only) of seven symptoms during the period of mood 
disturbance. Also recorded was the onset of first episode, the number of episodes, offset of last episode, and total duration of illness. Psychiatric assessments of child family members were made with the KSADSE (Epidemiologic Version) [45] and assessments of adult family members were made with the Structured Clinical Interview for DSM-IV [46]. Diagnoses were based on independent interviews with mothers and direct interviews with the children older than 12 years of age. Data were combined such that endorsement by either reporter resulted in a positive diagnosis. A committee of three psychiatrists, each board certified in both child and adult psychiatry, resolved all diagnostic uncertainties. The committee members were blind to the subjects' ascertainment group, ascertainment site, and data collected from family members.

All genotyping was conducted at the Psychiatric and Neurodevelopmental Genetics Unit of the Massachusetts General Hospital. Lab technicians were not aware of the source of the samples and all genotyping was performed in duplicate. The genotyping for SNPs in COMT (rs4680) and BDNF (rs6265) was performed using a single base extension reaction with allele discrimination by MassArray mass spectrometry system (Bruker-Sequenom) as previously described [47]. Genotyping of the SLC6A4 promoter (5-HTTLPR) polymorphisms was performed using the following protocol. Genomic DNA (5 ng) was amplified in a $7 \mu \mathrm{l}$ reaction using KlenTaq DNA Polymerase $(0.2 \mathrm{U})$, the proprietary KlenTaq Buffer $(1 \times)$, dNTPs (200 $\mu \mathrm{M}$ each), 5\% glycerol, Betaine $(1 \mathrm{M})$ and the marker specific primers $(0.2 \mu \mathrm{M})$. The SLC6A4 promoter VNTR primers were as follows: SLC6A4_PRO-F 6FAMATGCCAGCACCTAACCCCTAATGT, SLC6A4_PRO-R GGACCGCAAGGTGGGCGGGA. Amplification was performed with the following protocol: thirteen cycles of denaturation for 30 seconds at $93^{\circ} \mathrm{C}$, annealing for 30 seconds beginning at $61.5^{\circ} \mathrm{C}$ and dropped $0.5^{\circ} \mathrm{C}$ every cycle and primer extension at $72^{\circ} \mathrm{C}$ for 30 second; 37 cycles of denaturation for 30 seconds at $93^{\circ} \mathrm{C}$, annealing for 30 seconds at $55^{\circ} \mathrm{C}$ and primer extension at $72^{\circ} \mathrm{C}$ for $30 ; 72^{\circ} \mathrm{C}$ for 1 hour. Amplified products were pooled and combined with size standard (LIZ-250) before being analyzed on an ABI-3730. GeneMapper v3.5 was used to analyze the raw results from the ABI3730, however, a genotype was not considered final until two laboratory personnel had independently checked (and corrected) the GeneMapper results and both individuals were in agreement.

For the Transmission Disequilibrium Test (TDT) we used the PLINK (v1.0) software package [48]. Findings were considered statistically significant at $\mathrm{p}<0.05$.

\section{Results}

Bipolar offspring were $12.8 \pm 5.2$ years old at assessment and predominantly male $(74 \%, \mathrm{~N}=127)$. As described above, all children met criteria for DSM-IV bipolar I disorder. The mean age at onset was $7.5 \pm 4.7$ years of age and the clinical presentation was chronic $(3.5 \pm 3.8$ years duration), with rapid cycling ( $22.4 \pm 82.3$ episodes), and functional impairment (GAF score of $41.0 \pm 6.1$ ).

"Risk" alleles, designated to coincide with the previous reports of Geller et al, were in Hardy-Weinberg equilibrium for each gene assessed: BDNF (Val66, HWE p = 0.99), COMT (COMT-l allele, HWE $\mathrm{p}=0.91$ ), and SLC6A4 (HTTLPR short allele, HWE $\mathrm{p}=0.72$ ). Allele frequencies and association results are presented in Table 1. Seventysix parents were heterozygous for the BDNF Val66 allele, 142 parents were heterozygous for the COMT-l allele, and 146 parents were heterozygous for the SLC6A4 short allele. We failed to identify significant associations with any of these candidates.

\section{Discussion}

In this relatively large sample of families with a child proband diagnosed with DSM-IV bipolar-I disorder, we replicated earlier reports of no association with the disorder and COMT and SLC6A4 (SERT) [26,27]. We did not replicate the prior association with $B D N F$ [28]. Geller et al reported a statistically significant (FBAT p-value 0.014) association in which the Val66 allele was transmitted 21 times and not transmitted 9 times $(\mathrm{OR}=2.3,95 \% \mathrm{CI}=$ $1.09-4.98)$. We should have been able to detect an association of the magnitude observed in Geller et al [28]: the power to detect an odds ratio of 2.5 in our data was 0.89 at $\mathrm{p}<0.05$. If we pool the number of transmitted and not transmitted alleles in our data with that of Geller et al [28], the original estimate of association is attenuated and

Table I: TDT Analysis of candidate genes for pediatric bipolar disorder

\begin{tabular}{|c|c|c|c|c|c|c|c|c|}
\hline Gene & Marker & Allele' & Frequency & $\mathbf{T}: \mathbf{U}^{2}$ & OR & $95 \% \mathrm{Cl}$ & $\chi^{2}(1)$ & p-value \\
\hline BDNF & Val66Met & Val66 & 0.85 & $43: 35$ & 1.23 & $0.79-1.92$ & 0.8 & 0.37 \\
\hline COMT & Vall58Met & COMT-I & 0.50 & $85: 67$ & 1.27 & $0.92-1.75$ & 2.1 & 0.14 \\
\hline SLC6A4 & HTTLPR & Short & 0.46 & $73: 84$ & 0.87 & $0.63-1.19$ & 0.8 & 0.38 \\
\hline
\end{tabular}

T:U (trasmitted:untransmitted counts from basic TDT); OR 95\% Cl (odds ratio and 95\% confidence interval from basic TDT. I Val66 (G allele at rs6265), COMT-L (Met I58; A allele at rs4680), Short (I4-repeat allele). 276 parents were heterozygous for the BDNF Val66 allele, I42 parents were heterozygous for the COMT-I allele, and 146 parents were heterozygous for the SLC6A4 short allele. 
no longer statistically significant $(\mathrm{OR}=1.45,95 \% \mathrm{CI}=$ $0.99-2.1, \mathrm{p}=0.1$ ). Of course, a study of 170 families is modest for genetic association studies and the sample size needed to detect an odds ratio of 1.5 at $\mathrm{p}<0.05$ is 562 trios.

Despite the lack of replication observed in our data, BDNF may continue to be an interesting candidate gene for pediatric bipolar disorder. Although it was not found to be associated with bipolar disorder in genome-wide association studies of the disorder [49-52], Sklar et al [47] found association with $B D N F$ in a large candidate gene family study of adults with bipolar disorder. Although preliminary, a recent study suggests that decreased BDNF gene expression may play a role in the pathophysiology of bipolar disorder in children. Pandey et al. [53] observed significantly lower BDNF mRNA levels in lymphocytes of children with bipolar disorder compared to healthy control children. Furthermore, treatment with mood stabilizers normalized BDNF mRNA level at 8 weeks and change in symptoms of bipolar disorder was correlated with change in BDNF mRNA levels [53].

Our results should be interpreted in the context of methodological limitations. In an effort to replicate the extant literature we focused on single markers that do not cover the entire region of each gene. Although the power to detect large genetic effects was acceptable, it was quite low for smaller, more realistic, effect sizes. Thus, variation across the entire gene in samples of children large enough to detect small effects have yet to be conducted. Studies aimed at better understanding these associations and testing new candidate genes arising from the recent genome wide association studies are needed. Because the sample sizes available at independent sites are lacking, the creation of a viable and collaborative pediatric bipolar disorder genetics network will be critical to the success of these replication studies

\section{Conclusion}

Our study suggests that markers examined thus far in COMT and SLC6A4 are not associated with pediatric bipolar disorder and that if the val66met marker in BDNF is associated with pediatric bipolar disorder the magnitude of the association is much smaller than first reported.

\section{Abbreviations}

BDNF: is an abbreviation of brain-derived neurotrophicfactor gene; SLC6A4: represents the serotonin transporter gene; COMT: the catechol-O-methyltransferase gene; DSM-III, -IIIR, -IV: Diagnostic and Statistics Manual of Mental Disorders Versions III, III-revised, or IV.

\section{Competing interests}

Dr. Eric Mick receives research support from the following sources: McNeil Pediatrics, Ortho-McNeil Janssen Scien- tific Affairs, Pfizer, Shire Pharmaceuticals, and the National Institute of Mental Health (NIMH) and has had an advisory or consulting relationship with Pfizer, Shire Pharmaceuticals and Validus Pharmaceuticals.

Dr. Janet Wozniak receives research support from Eli Lilly and the National Institute of Mental Health (NIMH) and has a consulting relationship with the following: Pfizer, Shire Pharmaceuticals, Eli Lilly. Dr. Wozniak also serves on a speaker's bureau for both Eli Lilly and Janssen.

Dr Timothy Wilens receives grant support from the following sources: Abbott, McNeil, Lilly, NIH(NIDA), Merck, and Shire; is a speaker for the following speaker's bureaus: Lilly, McNeil, Novartis, and Shire; and is a consultant for Abbott, McNeil, Lilly, NIH (NIDA), Novartis, Merck, Shire.

Dr. Joseph Biederman is currently receiving research support from the following sources: Alza, AstraZeneca, Bristol Myers Squibb, Eli Lilly and Co., Janssen Pharmaceuticals Inc., McNeil, Merck, Organon, Otsuka, Shire, NIMH, and NICHD Dr. Joseph Biederman is currently a consultant/ advisory board member for the following pharmaceutical companies: Janssen, McNeil, Novartis, and Shire. Dr. Joseph Biederman is currently a speaker for the following speaker's bureaus: Janssen, McNeil, Novartis, Shire, and UCB Pharma, Inc. In previous years, Dr. Joseph Biederman received research support, consultation fees, or speaker's fees for/from the following additional sources: Abbott, AstraZeneca, Celltech, Cephalon, Eli Lilly and Co., Esai, Forest, Glaxo, Gliatech, NARSAD, NIDA, New River, Novartis, Noven, Neurosearch, Pfizer, Pharmacia, The Prechter Foundation, The Stanley Foundation, and Wyeth.

Dr. Faraone receives research support from and consults to Shire Pharmaceutical Development. He receives grant support from Eli Lilly and the National Institutes of Health.

\section{Authors' contributions}

All authors were involved in the design and execution of this study and contributed to the scientific content of this report. EM performed all statistical analyses and takes primary responsibility for the final report.

\section{Acknowledgements}

This work was supported in part by National Institute Health $(\mathrm{NIH})$ grants KOIMH065523 to Dr Mick, K08MH00I503 and ROIMH066237 to Dr Wozniak, ROIMH050657 and ROIHD0363I7 to Dr Biederman, ROIDA0I2945 to Dr Wilens, and ROIMH57934, ROIHD37694 and ROIMH066877 to Dr Faraone. This work was also supported by a grant from the Heinz C. Prechter Bipolar Research Fund and the support of members of the MGH Pediatric Psychopharmacology Council. 


\section{References}

I. Carlson GA: Bipolar Affective Disorders in Childhood and Adolescence. In Affective Disorders in Childhood and Adolescence: An Update Edited by: Cantwell DP, Carlson GA. New York: Spectrum Publications; 1983:61-83.

2. McElroy SL, Keck JPE, Pope JHG, Hudson JI, Faedda G, Swann AC: Clinical and research implications of the diagnosis of dysphoric or mixed mania or hypomania. American Journal of Psychiatry 1992, I49:1633-1644.

3. Biederman J, Mick E, Faraone SV, Van Patten S, Burback M, Wozniak J: A Prospective Follow Up Study of Pediatric Bipolar Disorder in boys with attention deficit/hyperactivity disorder. Journal of Affective Disorders 2004, 82S:SI7-S23.

4. Geller B, Williams M, Zimerman B, Frazier J, Beringer L, Warner K: Prepubertal and early adolescent bipolarity differentiate from ADHD by manic symptoms, grandiose delusions, ultrarapid or ultradian cycling. Journal of Affective Disorders 1998, 5 I:8|-9|.

5. Geller B, Craney JL, Bolhofner K, DelBello MP, Williams M, Zimerman B: One-Year Recovery and Relapse Rates of Children With a Prepubertal and Early Adolescent Bipolar Disorder Phenotype. American Journal of Psychiatry 200I, I 58:303-305.

6. Geller B, Tillman R, Bolhofner K, Zimerman B, Strauss NA, Kaufmann $\mathrm{P}$ : Controlled, blindly rated, direct-interview family study of a prepubertal and early-adolescent bipolar I disorder phenotype: morbid risk, age at onset, and comorbidity. Arch Gen Psychiatry 2006, 63: II30-II38.

7. Birmaher B, Axelson D, Strober M, Gill MK, Valeri S, Chiappetta L, Ryan N, Leonard H, Hunt J, lyengar S, Keller M: Clinical course of children and adolescents with bipolar spectrum disorders. Arch Gen Psychiatry 2006, 63:175-183.

8. Brotman MA, Kassem L, Reising MM, Guyer AE, Dickstein DP, Rich BA, Towbin KE, Pine DS, McMahon FJ, Leibenluft E: Parental diagnoses in youth with narrow phenotype bipolar disorder or severe mood dysregulation. Am J Psychiatry 2007, I 64: I 238- I24I.

9. Wozniak J, Biederman J, Kiely K, Ablon S, Faraone S, Mundy E, Mennin $D$ : Mania-like symptoms suggestive of childhood onset bipolar disorder in clinically referred children. I Am Acad Child Adolesc Psychiatry 1995, 34(7):867-876.

10. Findling RL, Gracious BL, McNamara NK, Youngstrom EA, Demeter CA, Branicky LA, Calabrese JR: Rapid, continuous cycling and psychiatric co-morbidity in pediatric bipolar I disorder. Bipolar Disorders 2001, 3:202-210.

II. Wilens TE, Biederman J, Adamson JJ, Henin A, Sgambati S, Gignac M, Sawtelle R, Santry A, Monuteaux MC: Further evidence of an association between adolescent bipolar disorder with smoking and substance use disorders: a controlled study. Drug Alcohol Depend 2008, 95:188-198.

12. Tsuang MT, Faraone SV: The Genetics of Mood Disorders Baltimore: The John Hopkins University Press; 1990.

13. Cardno AG, Marshall EJ, Coid B, Macdonald AM, Ribchester TR, Davies NJ, Venturi P, Jones LA, Lewis SW, Sham PC, Gottesman II, Farmer AE, McGuffin P, Reveley AM, Murray RM: Heritability estimates for psychotic disorders: the Maudsley twin psychosis series. Arch Gen Psychiatry 1999, 56:162-168.

14. Kendler KS, Pedersen N, Johnson L, Neale MC, Mathe AA: A pilot Swedish twin study of affective illness, including hospital- and population-ascertained subsamples. Arch Gen Psychiatry 1993, 50:699-700.

15. Kendler KS, Pedersen NL, Neale MC, Mathe AA: A pilot Swedish twin study of affective illness including hospital- and population-ascertained subsamples: results of model fitting. Behav Genet 1995, 25:217-232.

16. Kieseppa T, Partonen T, Haukka J, Kaprio J, Lonnqvist J: High concordance of bipolar I disorder in a nationwide sample of twins. Am J Psychiatry 2004, 16 I:1814-1821.

17. McGuffin P, Rijsdijk F, Andrew M, Sham P, Katz R, Cardno A: The heritability of bipolar affective disorder and the genetic relationship to unipolar depression. Arch Gen Psychiatry 2003, 60:497-502.

18. Smoller JW, Finn CT: Family, twin, and adoption studies of bipolar disorder. American Journal of Medical Genetics 2003, I 23 C:48.

19. Dwyer JT, DeLong GR: A family history study of twenty probands with childhood manic-depressive illness. J Am Acad Child Adolesc Psychiatry 1987, 26:176-180.
20. Kutcher S, Marton P: Affective disorders in first-degree relatives of adolescent onset bipolars, unipolars, and normal controls. J Am Acad Child Adolesc Psychiatry 1991, 30:75-78.

21. Neuman RJ, Geller B, Rice JP, Todd RD: Increased prevalence and earlier onset of mood disorders among relatives of prepubertal versus adult probands. J Am Acad Child Adolesc Psychiatry 1997, 36:466-473.

22. Strober M, Morrell W, Burroughs J, Lampert C, Danforth H, Freeman $\mathrm{R}$ : A family study of bipolar I disorder in adolescence. Early onset of symptoms linked to increased familial loading and lithium resistance. J Affect Disord 1988, I 5:255-268.

23. Wozniak J, Biederman J, Mundy E, Mennin D, Faraone SV: A pilot family study of childhood-onset mania. J Am Acad Child Adolesc Psychiatry 1995, 34:1577-I583.

24. Wilens TE, Biederman J, Adamson J, Monuteaux M, Henin A, Sgambati S, Santry A, Faraone SV: Association of bipolar and substance use disorders in parents of adolescents with bipolar disorder. Biol Psychiatry 2007, 62: I29-134.

25. Craddock N, Forty L: Genetics of affective (mood) disorders. Eur J Hum Genet 2006, I 4:660-668.

26. Geller B, Cook E: Serotonin transporter gene (HTTLPR) is not in linkage disequilibrium with prepubertal and early adolescent bipolarity. Biological Psychiatry 1999, 45:1230-1233.

27. Geller B, Cook EH Jr: Ultradian rapid cycling in prepubertal and early adolescent bipolarity is not in transmission disequilibrium with val/met COMT alleles. Biological Psychiatry 2000, 47:605-609.

28. Geller B, Badner JA, Tillman R, Christian SL, Bolhofner K, Cook EH $J \mathrm{r}$ : Linkage disequilibrium of the brain-derived neurotrophic factor Val66Met polymorphism in children with a prepubertal and early adolescent bipolar disorder phenotype. The American Journal of Psychiatry 2004, I 6 I: 1698.

29. Geller B, Tillman R, Bolhofner K, Hennessy K, Cook EH Jr: GAD I single nucleotide polymorphism is in linkage disequilibrium with a child bipolar I disorder phenotype. I Child Adolesc Psychopharmacol 2008, I 8:25-29.

30. Lesch K, Bengel D, Heils A, Sabol S, Greenberg B, Petri S, Benjamin J, Muller C, Hamer D, Murphy D: Association of anxiety-related traits with a polymorphism in the serotinin transporter gene regulatory region. Science 1996, 274: I527-1532.

31. Axelrod J, Tomchick R: Enzymatic O-methylation of epinephrine and other catechols. J Biol Chem 1958, 233:702-705.

32. Lachman HM, Papolos DF, Saito T, Yu YM, Szumlanski CL, Weinshilboum RM: Human catechol-O-methyltransferase pharmacogenetics: description of a functional polymorphism and its potential application to neuropsychiatric disorders. Pharmacogenetics 1996, 6:243-250.

33. Rylett RJ, Williams LR: Role of neurotrophins in cholinergicneurone function in the adult and aged CNS. Trends Neurosci 1994, I 7:486-490.

34. Egan MF, Kojima M, Callicott JH, Goldberg TE, Kolachana BS, Bertolino A, Zaitsev E, Gold B, Goldman D, Dean M, Lu B, Weinberger DR: The BDNF val66met polymorphism affects activitydependent secretion of BDNF and human memory and hippocampal function. Cell 2003, I I 2:257-269.

35. Erlander MG, Tillakaratne NJ, Feldblum S, Patel N, Tobin AJ: Two genes encode distinct glutamate decarboxylases. Neuron 1991, 7:91-100.

36. $\mathrm{Bu} \mathrm{DF}$, Tobin AJ: The exon-intron organization of the genes (GADI and GAD2) encoding two human glutamate decarboxylases (GAD67 and GAD65) suggests that they derive from a common ancestral GAD. Genomics 1994, 2 1:222-228.

37. Addington AM, Gornick M, Duckworth J, Sporn A, Gogtay N, Bobb A, Greenstein D, Lenane M, Gochman P, Baker N, Balkissoon R, Vakkalanka RK, Weinberger DR, Rapoport JL, Straub RE: GAD I (2q3I.I), which encodes glutamic acid decarboxylase (GAD67), is associated with childhood-onset schizophrenia and cortical gray matter volume loss. Mol Psychiatry 2005, 10:581-588.

38. Madras BK, Miller GM, Fischman AJ: The dopamine transporter: relevance to attention deficit hyperactivity disorder (ADHD). Behavioural Brain Research 2002, I 30:57-63.

39. Madras BK, Miller GM, Fischman AJ: The dopamine transporter and attention-deficit/hyperactivity disorder. Biol Psychiatry 2005, 57:1397-1409. 
40. Mick E, Kim JW, Biederman J, Wozniak J, Wilens T, Spencer T, Smoller JW, Faraone SV: Family based association study of pediatric bipolar disorder and the dopamine transporter gene (SLC6A3). Am J Med Genet B Neuropsychiatr Genet 2008, 147B: I I82-I I 85 .

41. Biederman J, Monuteaux M, Mick E, Spencer T, Wilens T, Silva J, Snyder L, Faraone SV: Young Adult Outcome of Attention Deficit Hyperactivity Disorder: A Controlled 10 year Prospective Follow-Up Study. Psychological Medicine 2006, 36:167-I79.

42. Biederman J, Monuteaux MC, Mick E, Spencer T, Wilens TE, Klein KL, Price JE, Faraone SV: Psychopathology in females with attention-deficit/hyperactivity disorder: a controlled, five-year prospective study. Biol Psychiatry 2006, 60:1098-1 105.

43. Faraone SV, Biederman J, Spencer T, Mick E, Murray K, Petty C, Adamson J], Monuteaux MC: Diagnosing adult attention deficit hyperactivity disorder: are late onset and subthreshold diagnoses valid? Am J Psychiatry 2006, 163:1720-1729.

44. Wozniak J, Biederman J, Kwon A, Mick E, Faraone SV, Orlovsky K, Schnare L, Cargol C, Van Grondelle A: How cardinal are cardinal symptoms in pediatric bipolar disorder?: An examination of clinical correlates. Biological Psychiatry 2005, 58:583-588.

45. Orvaschel H: Schedule for Affective Disorder and Schizophrenia for School-Age Children Epidemiologic Version 5th edition. Ft. Lauderdale: Nova Southeastern University, Center for Psychological Studies; 1994.

46. First MB, Spitzer RL, Gibbon M, Williams JBW: Structured Clinical Interview for DSM-IV Axis I Disorders-Clinician Version (SCID-CV) Washington, DC: American Psychiatric Press; 1997.

47. Sklar P, Gabriel SB, Mclnnis MG, Bennett P, Lim YM, Tsan G, Schaffner S, Kirov G, Jones I, Owen M, Craddock N, DePaulo JR, Lander ES: Family-based association study of 76 candidate genes in bipolar disorder: BDNF is a potential risk locus. Brain-derived neutrophic factor. Mol Psychiatry 2002, 7:579-593.

48. Purcell S, Neale B, Todd-Brown K, Thomas L, Ferreira MA, Bender D, Maller J, Sklar P, de Bakker PI, Daly MJ, Sham PC: PLINK: a tool set for whole-genome association and population-based linkage analyses. Am J Hum Genet 2007, 8 I:559-575.

49. Baum AE, Akula N, Cabanero M, Cardona I, Corona W, Klemens B, Schulze TG, Cichon S, Rietschel M, Nothen MM, Georgi A, Schumacher J, Schwarz M, Abou Jamra R, Hofels S, Propping P, Satagopan J, Detera-Wadleigh SD, Hardy J, McMahon FJ: A genome-wide association study implicates diacylglycerol kinase eta (DGKH) and several other genes in the etiology of bipolar disorder. Mol Psychiatry 2008, 13:197-207.

50. Baum AE, Hamshere M, Green E, Cichon S, Rietschel M, Noethen MM, Craddock N, McMahon FJ: Meta-analysis of two genomewide association studies of bipolar disorder reveals important points of agreement. Mol Psychiatry 2008, 13:466-467.

5I. Sklar P, Smoller JW, Fan J, Ferreira MA, Perlis RH, Chambert K, Nimgaonkar VL, McQueen MB, Faraone SV, Kirby A, de Bakker PI, Ogdie MN, Thase ME, Sachs GS, Todd-Brown K, Gabriel SB, Sougnez C, Gates C, Blumenstiel B, Defelice M, Ardlie KG, Franklin J, Muir W], McGhee KA, Macintyre DJ, McLean A, Vanbeck M, McQuillin A, Bass NJ, Robinson M, Lawrence J, Anjorin A, Curtis D, Scolnick EM, Daly M], Blackwood DH, Gurling HM, Purcell SM: Whole-genome association study of bipolar disorder. Mol Psychiatry 2008, 13:558-569.

52. WTCCC TWTCCC: Genome-wide association study of $\mathbf{1 4 , 0 0 0}$ cases of seven common diseases and 3,000 shared controls. Nature 2007, 447:66I-678.

53. Pandey GN, Rizavi HS, Dwivedi Y, Pavuluri MN: Brain-Derived Neurotrophic Factor Gene Expression in Pediatric Bipolar Disorder: Effects of Treatment and Clinical Response. J Am Acad Child Adolesc Psychiatry 2008.

\section{Pre-publication history}

The pre-publication history for this paper can be accessed here:

http://www.biomedcentral.com/1471-244X/9/2/prepub
Publish with Biomed Central and every scientist can read your work free of charge

"BioMed Central will be the most significant development for disseminating the results of biomedical research in our lifetime. "

Sir Paul Nurse, Cancer Research UK

Your research papers will be:

- available free of charge to the entire biomedical community

- peer reviewed and published immediately upon acceptance

- cited in PubMed and archived on PubMed Central

- yours - you keep the copyright
BioMedcentral 